\title{
SINTERED PERMANENT MAGNETS PREPARED FROM HYDROGENATED (Nd-Fe-B STRIP-CAST ALLOY + $\mathrm{Pr}_{3}(\mathrm{Co}, \mathrm{Cu})$ COMPOUND) MIXTURE
}

\author{
1,2Pavel A. PROKOFEV, ${ }^{2}$ Natalia B. KOLCHUGINA, ${ }^{3}$ Kateřina SKOTNICOVÁ, ${ }^{2}$ Gennadii S. \\ BURKHANOV, ${ }^{1,4}$ Mark V. ZHELEZNYI, ${ }^{1}$ Nikolay A. DORMIDONTOV, ${ }^{1}$ Anna S. BAKULINA, \\ ${ }^{3}$ Tomáš ČEGAN, ${ }^{3}$ Jan JUŘıCA \\ ${ }^{1}$ Baikov Institute of Metallurgy and Materials Science, Russian Academy of Sciences, Moscow, Russia, \\ natalik014@yandex.ru \\ 2JSC Spetsmagnit, Moscow, Russia, pav3387@yandex.ru \\ ${ }^{3}$ Vysoka škola báňská - Technical University of Ostrava, Czech Republic, EU, Katerina.Skotnicova@vsb.cz \\ ${ }^{4}$ National University of Science and Technology MISiS, Moscow, Russia
}

https://doi.org/10.37904/metal.2020.3608

\begin{abstract}
The application of powder blending procedure shows promise in manufacturing Nd-Fe-B magnets; in this case, hydrides, oxides, intermetallic compounds, etc. are used as one of the mixture components. The application of these additions allows one to increase the hysteretic characteristics of $\mathrm{Nd}-\mathrm{Fe}-\mathrm{B}$ magnets at the expense of realized grain-boundary diffusion and grain-boundary structuring processes since these characteristics of the magnets are highly sensitive to their microstructure, composition of phases, and distribution of alloy components as well. This study is focused on the possibility of using the $\operatorname{Pr}_{3} \mathrm{Co}_{0.6} \mathrm{Cu}_{0.4} \mathrm{H}_{x}$ composition as the addition to the powder mixture for manufacturing $\mathrm{Nd}-\mathrm{Fe}-\mathrm{B}$ magnets and on the processes occurred during hydrogen treatment of the addition. The base alloy having the composition Nd-24.0, Pr-6.5, Dy-0.5, B-1.0, Al0.2 , Fe-balance was prepared by strip-casting and subjected to hydrogen decrepitation at $270{ }^{\circ} \mathrm{C}$ for $1 \mathrm{~h}$. The $\mathrm{Pr}_{3} \mathrm{C}_{0.6} \mathrm{Cu}_{0.4}$ alloy was prepared by arc melting in an argon atmosphere and subjected to homogenizing annealing at $600{ }^{\circ} \mathrm{C}$ for $90 \mathrm{~h}$ and subsequent hydrogenation under the conditions used for the strip-cast alloy. The phase composition of $\mathrm{Pr}_{3} \mathrm{Co}_{0.6} \mathrm{Cu}_{0.4} \mathrm{H}_{\mathrm{x}}$ was studied by $\mathrm{X}$-ray diffraction analysis, DTA, scanning electron microscopy, and electron microprobe analysis. The $\mathrm{Pr}_{3} \mathrm{Co}_{0.6} \mathrm{Cu}_{0.4} \mathrm{H}_{x}$ composition was shown to undergo the hydrogenolysis with the formation of $\mathrm{PrH}_{\mathrm{x}}$ hydride (or hydrogen solid solution in $\mathrm{Pr}$ ), $\mathrm{Co}+\mathrm{Cu}$ fine mixture, and PrCu compound. The behavior of the additions in manufacturing sintered permanent magnets is analyzed from the viewpoint of the grain-boundary structuring effect of the addition. The sintered magnet prepared from the hydrogenated mixture Nd-Fe-B strip-cast alloy $+\operatorname{Pr}_{3}(\mathrm{Co}, \mathrm{Cu})$ compound exhibits the following hysteretic parameters: $B_{r}=1.35 \mathrm{~T}, j_{H c}=1008 \mathrm{kA} / \mathrm{m}$, and $(B H)_{\max }=349 \mathrm{~kJ} / \mathrm{m}^{3}$.
\end{abstract}

Keywords: Nd-Fe-B magnets, blending procedure, intermetallic compound, coercive force, grain boundary

\section{INTRODUCTION}

Sintered Nd-Fe-B permanent magnets are used in many electronic devices, such as hybrid engines, medical equipment, wind generators, etc. A wide variety of applications of $\mathrm{Nd}-\mathrm{Fe}-\mathrm{B}$ magnets stimulates the development of approaches allowing the phase composition and microstructure of magnets to be optimized and the hysteretic characteristics to be increased. One of the effective approaches to improving the hysteresis properties is the use of binary mixture technology with the implementation of grain boundary diffusion and grain boundary restructuring processes [1-5]. A number of studies are focused on the possibility of increasing the hysteretic characteristics of sintered Nd-Fe-B permanent magnets in using Pr-Cu system alloys as 
additives for the implementation of diffusion processes and structuring grain boundaries. In [6], the $\operatorname{Pr}_{68} \mathrm{Cu}_{32}$ and $\mathrm{Pr}_{35} \mathrm{Dy}_{35} \mathrm{Cu}_{30}$ alloys in the form of foils were used. The coercivity enhancement of the diffused magnets by $\mathrm{Pr}_{68} \mathrm{Cu}_{32}$ alloy was mainly resulted from relatively continuous and thin intergranular layers isolating $\mathrm{Nd}_{2} \mathrm{Fe}_{14} \mathrm{~B}-$ based grains, which were achieved only by post-diffusion annealing. It was observed that the grain boundary phases of the $\mathrm{Pr}_{68} \mathrm{Cu}_{32}$-diffused Nd-Fe-B magnets became more continuous and clear because $\mathrm{Pr}$ and $\mathrm{Cu}$ dissolved and diffused into the intergranular phase adjacent to $\mathrm{Nd}_{2} \mathrm{Fe}_{14} \mathrm{~B}$ grains. In work [7], the mixed hydride ( $\mathrm{Pr}, \mathrm{Dy}, \mathrm{Cu}$ )- $\mathrm{Hx}$ was used as the additive. It was shown that in using the $2 \mathrm{wt} \%(\mathrm{Pr}, \mathrm{Dy}, \mathrm{Cu})-\mathrm{Hx}$ addition, the significant increase in the coercive force from 1200 to $1456 \mathrm{kA} / \mathrm{m}$ is observed. In [8], the $\mathrm{Pr}_{83} \mathrm{Cu}_{17}$ (wt\%) eutectic alloy was used as an additive; the dependence of the coercive force on the content of the additive is shown. The coercivity of the prepared alloy is shown to be highly sensitive to the annealing temperature. After optimal heat treatment, the coercive force increases from 680 to 1024 and to $1176 \mathrm{kA} / \mathrm{m}$ with additive contents of 0-5 and $10 \mathrm{wt} \%$. Pr-Cu addition slightly enlarges grain sizes and introduces new boundary phase constitutions: Cu-higher phase ( $\left.h-\mathrm{RE}_{2} \mathrm{O}_{3}\right)$ and $\mathrm{Cu}$ lower phase (fcc $\mathrm{REO}$ ).

Fangming Wan et al. [9] have studied the Pr-Cu alloy diffused into Nd-Fe-B sintered magnets and reported that the coercivity increased from 1120 (original magnet) to $1680 \mathrm{kA} / \mathrm{m}$ (diffusion-treated magnet). This result was attributed to the grain size of the magnets, which decreased from 6.5 to $4.5 \mu \mathrm{m}$ and the thickness of grain boundary phases approximately increased from 4 to $20 \mathrm{~nm}$. Thus, it was indicated that the pre-diffusion process could suppress the formation of coarse grain regions due to $\mathrm{Pr}-\mathrm{Cu}$ alloy addition but the low melting point $\mathrm{Pr}-\mathrm{Cu}$ alloys could not diffuse uniformly.

In [10], the effect of Pr-Co additives on the coercive force and thermal stability was investigated. It is shown that the increase in the content of the additive to $15 \mathrm{wt} \%$ leads to the sharp decrease in the intrinsic coercivity from about 14.8 to $320 \mathrm{kA} / \mathrm{m}$. According to the authors' opinion, this is associated with the formation of new ferromagnetic phases, in particular, the soft magnetic $(\mathrm{NdPr})(\mathrm{FeCo})_{2}$ phases. However, the further increase in the additive content from 15 to $20 \%$, results in a sharp increase in the coercive force, which is associated with the formation of the nonmagnetic phase $(\mathrm{NdPr})_{3}(\mathrm{FeCo})$ and the transformation of the phase $(\mathrm{NdPr})(\mathrm{FeCo})_{2}$ from soft ferromagnet into the non-magnetic phase. Thus, the use of $\mathrm{Pr}-\mathrm{Cu}$ and $\mathrm{Pr}$-Co systems as additives in manufacturing the $\mathrm{Nd}-\mathrm{Fe}-\mathrm{B}$ permanent magnets allows one to modify the phase composition and properties of them.

The aim of this work is to study the possibility of using the hydrogenated $\mathrm{Pr}_{3} \mathrm{Co}_{0.6} \mathrm{Cu}_{0.4}$ compound as an additive in manufacturing $\mathrm{Nd}-\mathrm{Fe}-\mathrm{B}$ permanent magnets by powder blending procedure.

\section{EXPERIMENTAL}

The base alloy (wt\%) Nd-24.0, Pr-6.5, Dy-0.5, B-1.0, Al-0.2, Fe-balance was prepared by strip-casting technique and subjected to hydrogen decrepitation during heating to $270{ }^{\circ} \mathrm{C}$ in a hydrogen flow at a pressure of $0.1 \mathrm{MPa}$ and subsequent $1 \mathrm{~h}$ dwell at this temperature. The $\mathrm{Pr}_{3} \mathrm{Co}_{0.6} \mathrm{Cu}_{0.4}$ alloy was prepared by arc melting of starting components (Pr-99.5 at\%, electrolytic Co K-1 grade, and oxygen-free copper) in an argon atmosphere using a water-cooled copper mould and a nonconsumable tungsten electrode. The ingot was subjected to homogenizing annealing at $600^{\circ} \mathrm{C}$ for $90 \mathrm{~h}$ followed by rapid cooling $\left(20^{\circ} \mathrm{C} / \mathrm{min}\right)$. The ingot was subjected to hydrogenation under conditions used for the strip-casting alloy, namely, during heating to $270{ }^{\circ} \mathrm{C}$ in a hydrogen flow at a pressure of $0.1 \mathrm{MPa}$ and subsequent $1 \mathrm{~h}$ holding at this temperature.

The structure of the hydrogenated composition was studied on QUANTA 450 FEG scanning electron microscope equipped with an EDX APOLLO X microanalyzer; the back-scattered electron mode image was used. The phase composition of $\operatorname{Pr}_{3}(\mathrm{Co}, \mathrm{Cu}) \mathrm{H}_{\mathrm{x}}$ was studied by $\mathrm{X}$-ray diffraction (XRD) analysis using an Ultima IV (Rigaku», Japan) diffractometer equipped with a "D/teX" detector and CuKa radiation; the scanning step is $0.001^{\circ}$. The differential thermal analysis of the hydrogenated $\mathrm{Pr}_{3}(\mathrm{Co}, \mathrm{Cu}) \mathrm{H}_{\mathrm{x}}$ composition was carried out in an argon atmosphere at a heating rate of $15^{\circ} \mathrm{C} / \mathrm{min}$ using a Setaram Setsys -1750 installation. 
The mixture of the $\operatorname{Pr}_{3}(\mathrm{Co}, \mathrm{Cu}) \mathrm{H}_{x}$ and hydrogen-decrepitated strip-casting alloy was subjected to fine milling for $40 \mathrm{~min}$ to an average particle size of $3 \mu \mathrm{m}$ using a vibratory mill and isopropyl alcohol medium. After wet compaction of the pulp in a transverse magnetic field of $1500 \mathrm{kA} / \mathrm{m}$, blanks of magnets were sintered at $T=$ $1080^{\circ} \mathrm{C}$ for $2 \mathrm{~h}$ and subjected to post-sintering annealing at $500{ }^{\circ} \mathrm{C}$ for $2 \mathrm{~h}$. The hysteretic properties were measured using a hysteresisgraph.

\section{RESULTS AND DISCUSSION}

\subsection{Study of the structure and phase composition of $\operatorname{Pr}_{3}\left(\mathrm{Co}_{0.6} \mathrm{Cu}_{0.4}\right) \mathrm{H}_{x}$}

To study the usefulness of application of the $\operatorname{Pr}_{3}(\mathrm{Co}, \mathrm{Cu}) \mathrm{H}_{\mathrm{x}}$ addition in manufacturing sintered Nd-Fe-B magnets, its phase composition was investigated in detail.

The microstructure (SEM) of hydrogenated $\mathrm{Pr}_{3} \mathrm{CO}_{0.6} \mathrm{Cu}_{0.4} \mathrm{H}_{x}$ composition is shown in Figure 1. Results of electron microprobe analysis (EMA) of the found phases are given in Table 1.

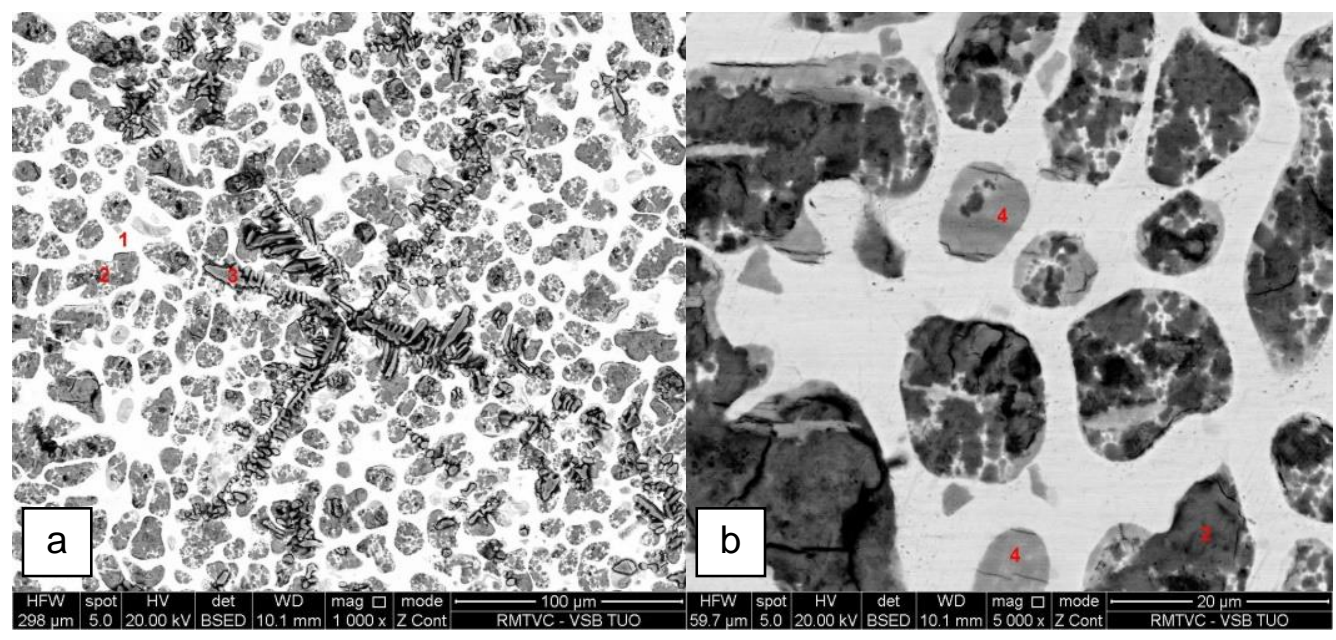

Figure 1 Microstructure (SEM, BSE mode) of the hydrogenated $\mathrm{Pr}_{3} \mathrm{Co}_{0.6} \mathrm{Cu}_{0.4} \mathrm{H}_{\mathrm{x}}$ composition; points of electron microprobe analysis are shown

According to the data, the hydrogenated composition is characterized by multi-phase structure. Regular rounded and dendritic inclusions are observed in the matrix phase (Figure 1a, point 1), the phase composition of which is complex and is based on Pr-rich phases. Taking into account the fact that data on the mutual solubility of components in the found phases are absent, we have calculated the phase composition of phase 1 using stoichiometry of the phases and EMA data. The assumed phase composition of the matrix phase includes (mole fractions) $\operatorname{Pr}_{3} \mathrm{Co}$ (0.29), $\operatorname{PrCu}(0.43), \operatorname{Pr}(0.28)$. It is likely that $\mathrm{PrCu}$ and $\operatorname{Pr}$ form the eutectic. Inclusions (points 2, 3,4) observed in the matrix show the presence of $\operatorname{Pr}$ with small contents of cobalt and copper. It should be noted that observed dendritic inclusions (Figure 1a) also corresponds to Pr.

According to DTA data (Figure 2) for the hydrogenated $\mathrm{Pr}_{3} \mathrm{Co}_{0.6} \mathrm{Cu}_{0.4} \mathrm{H}_{\mathrm{x}}$ composition, several thermal effects are observed. It should be noted that the phase composition of $\operatorname{Pr}_{3} \mathrm{Co}_{0.6} \mathrm{Cu}_{0.4} \mathrm{H}_{\mathrm{x}}$ is due to the partial hydrogenolysis of $\mathrm{Pr}_{3} \mathrm{Co}_{0.6} \mathrm{Cu}_{0.4}$. In accordance to the $\mathrm{Pr}$-Cu and $\mathrm{Pr}$-Co phase diagrams [11], the thermal effect at $\sim 734^{\circ} \mathrm{C}$ is related to the solidus for the two-phase region $\operatorname{Pr}$ crystallites $+(\operatorname{PrCu}+\operatorname{Pr})$ eutectic. The onset of the thermal effect corresponding to $\sim 420^{\circ} \mathrm{C}$ can indicate the allotropic transformation of Co (cubic to hexagonal). The late effect is overlapped with the thermal effect related to the $L \rightarrow \operatorname{PrCu}+\operatorname{Pr}$ eutectic reaction. Thus, the multiphase composition added to the powder mixture in manufacturing sintered permanent magnet contains mainly $\operatorname{Pr}\left(\mathrm{PrH}_{\mathrm{x}}\right)$ and $\mathrm{PrCu}$. 
Table 1 Results of electron microprobe analysis (at. \%) of the $\mathrm{Pr}_{3} \mathrm{Co}_{0.6} \mathrm{Cu}_{0.4} \mathrm{Hx}$ addition

\begin{tabular}{|c|c|c|c|}
\hline Elements & Pr & Co & Cu \\
\hline Phase_1_1 & 7.7 & 7.1 & 22.2 \\
\hline Phase_1_2 & 70.9 & 7.5 & 21.6 \\
\hline Phase_1_3 & 71.3 & 7.1 & 21.8 \\
\hline Phase_1_averaged & 71.0 & 7.2 & 1.0 \\
\hline Phase_2_1 & 98.7 & 0.3 & 0.3 \\
\hline Phase_2_2 & 99.7 & 0.0 & 0.7 \\
\hline Phase_2_3 & 99.1 & 0.2 & 0.6 \\
\hline Phase_2_averaged & 99.2 & 0.2 & 0.6 \\
\hline Phase_3_1 & 99.4 & 0.0 & 0.4 \\
\hline Phase_3_2 & 99.6 & 0.0 & 0.3 \\
\hline Phase_3_3 & 99.7 & 0.0 & 0.4 \\
\hline Phase_3_averaged & 99.6 & 0.0 & 0.7 \\
\hline Phase_4_1 & 99.3 & 0.0 & 0.5 \\
\hline Phase_4_2 & 99.5 & 0.0 & 2.0 \\
\hline Phase_4_3 & 97.8 & 0.2 & 1.1 \\
\hline
\end{tabular}

These results were confirmed by X-ray diffraction data. The X-ray diffraction data are given in Figure $\mathbf{3}$ and Table 2. The formation of the $\mathrm{Co}_{3} \mathrm{PrH}_{\mathrm{x}}$ is unlike; however, the thermal effect at $\sim 1050{ }^{\circ} \mathrm{C}$ (related to the peritectic reaction of the $\mathrm{Co}_{3} \mathrm{Pr}$ phase) is observed. The total content of $\mathrm{Pr}$ and $\mathrm{PrHx}$ phase is estimated to be $\sim 50 \%$. Among the alloy components, only Co can diffuse into the $\mathrm{Nd}_{2} \mathrm{Fe}_{14} \mathrm{~B}$-based phase grains (the reflection of $\mathrm{Co}$ is observed in the X-ray diffraction pattern in Fig. 2). Cobalt cannot be observed in the alloy structure by SEM since, as it was shown in $[12,13]$, the hydrogenolysis of the $R_{3}$ Co compounds (with $R=T b$, Dy) leads to their decomposition with the formation of fine $\mathrm{Co}$ and $\mathrm{Cu}$ particles. The other components will improve the grain boundary structure via enhanced wettability between the $\mathrm{Nd}_{2} \mathrm{Fe}_{14} \mathrm{~B}$-based grains and the $\mathrm{Nd}$-rich phase and decreasing exchange coupling between $\mathrm{Nd}_{2} \mathrm{Fe}_{14} \mathrm{~B}$-based grains [14, 15]. According to [12], cobalt, in using $\mathrm{Tb}_{3} \mathrm{Co}_{0.6} \mathrm{Cu}_{0.4} \mathrm{H}_{\mathrm{x}}$ addition, forms core/shell microstructure, which favors the improved thermal stability of coercive force [16].

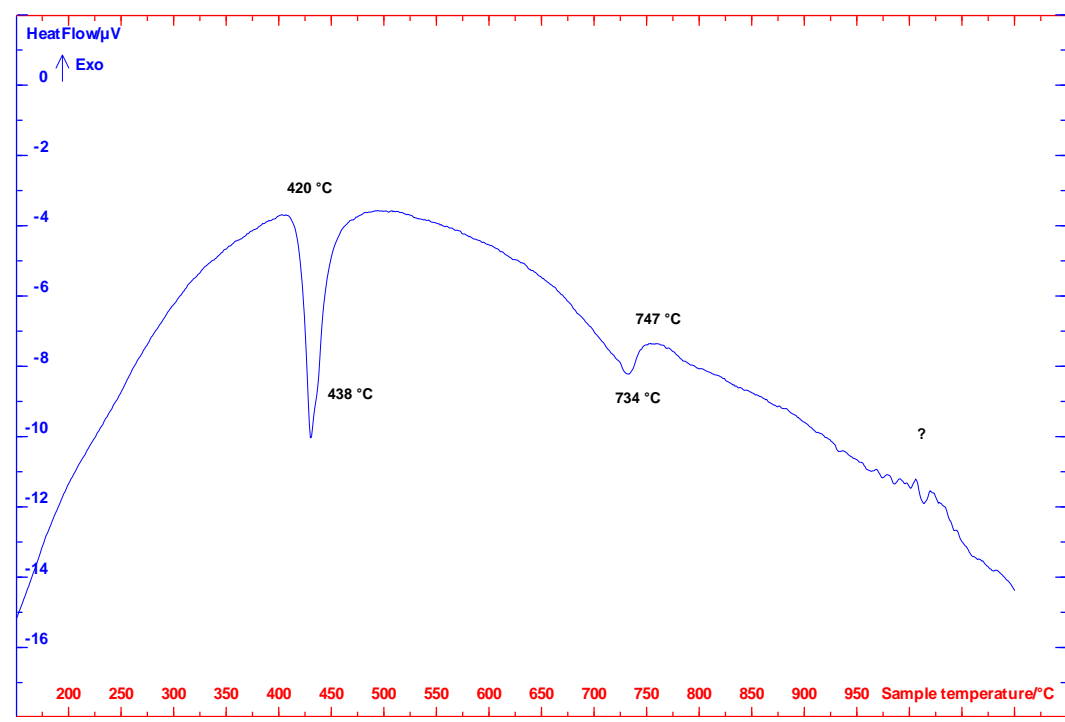

Figure 2 DTA curve of the $\mathrm{Pr}_{3} \mathrm{Co}_{0.6} \mathrm{Cu}_{0.4} \mathrm{H}_{x}$ composition measured during heating at a rate of $15^{\circ} \mathrm{C} / \mathrm{min}$ $\left(\mathrm{Al}_{2} \mathrm{O}_{3}\right.$ crucible, heating $20-1150^{\circ} \mathrm{C}$, inert dynamic atmosphere $\operatorname{Ar}(6 \mathrm{~N}), m=67 \mathrm{mg}$ ) 


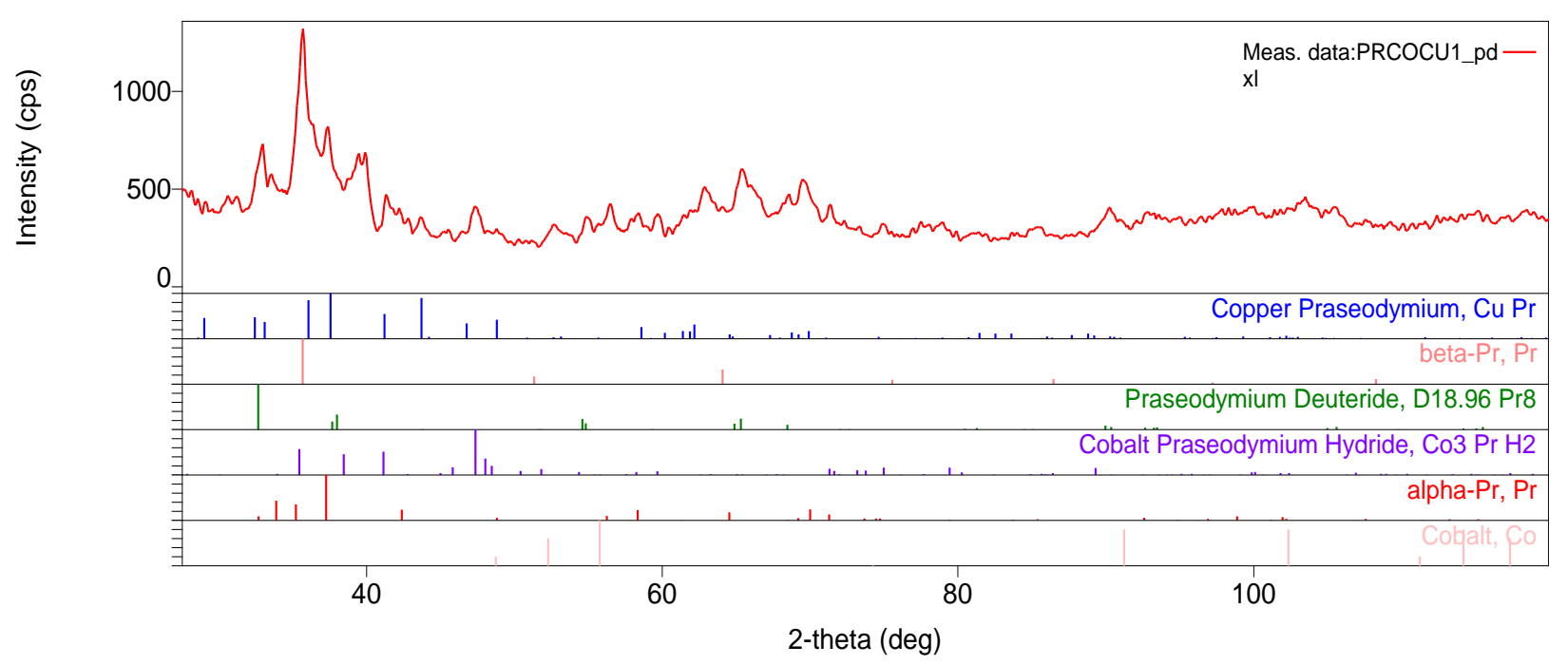

Figure $3 \mathrm{X}$-ray diffraction pattern of the $\operatorname{Pr}_{3}(\mathrm{Co}, \mathrm{Cu}) \mathrm{H}_{x}$ composition

Table 2 Results of quantitative X-ray phase analysis

\begin{tabular}{|c|c|c|c|c|c|c|}
\hline Phase & $\mathrm{CuPr}$ & $\beta-P r$ & $\mathrm{PrH}_{2}$ & $\mathrm{Co}_{3} \mathrm{PrH}_{2}$ & $\boldsymbol{\alpha}-\mathrm{Pr}$ & Co \\
\hline Content $(w t \%)$ & 22.0 & 28 & 8.0 & 12.0 & 23.2 & 7.0 \\
\hline
\end{tabular}

\subsection{Magnetic properties of sintered magnet}

The sintered magnets were prepared using strip-casting alloy subjected to hydrogen decrepitation and either $2 \% \mathrm{Pr}_{3} \mathrm{Co}_{0.6} \mathrm{Cu}_{0.4}$ composition undergone the hydrogenolysis or $2 \% \mathrm{PrH}_{\mathrm{x}}$. The magnets in the form of disk 48 $\mathrm{mm}$ in diameter and $8 \mathrm{~mm}$ in height were sintered at $1080^{\circ} \mathrm{C}$ and subsequently subjected to post-sintering annealing at $500{ }^{\circ} \mathrm{C}$ for $2 \mathrm{~h}$. The density of the magnet prepared with $2 \% \mathrm{Pr}_{3} \mathrm{Co}_{0.6} \mathrm{Cu}_{0.4} \mathrm{H}_{x}$ is $7.52 \mathrm{~g} / \mathrm{cm}^{3}$. The magnetic hysteresis properties of the magnet are given in Figure 4 and Table 3 . As the reference magnet, we use the sintered magnet prepared in using the strip-casting alloy and $2 \% \mathrm{PrH}_{\mathrm{x}}$ as the addition.

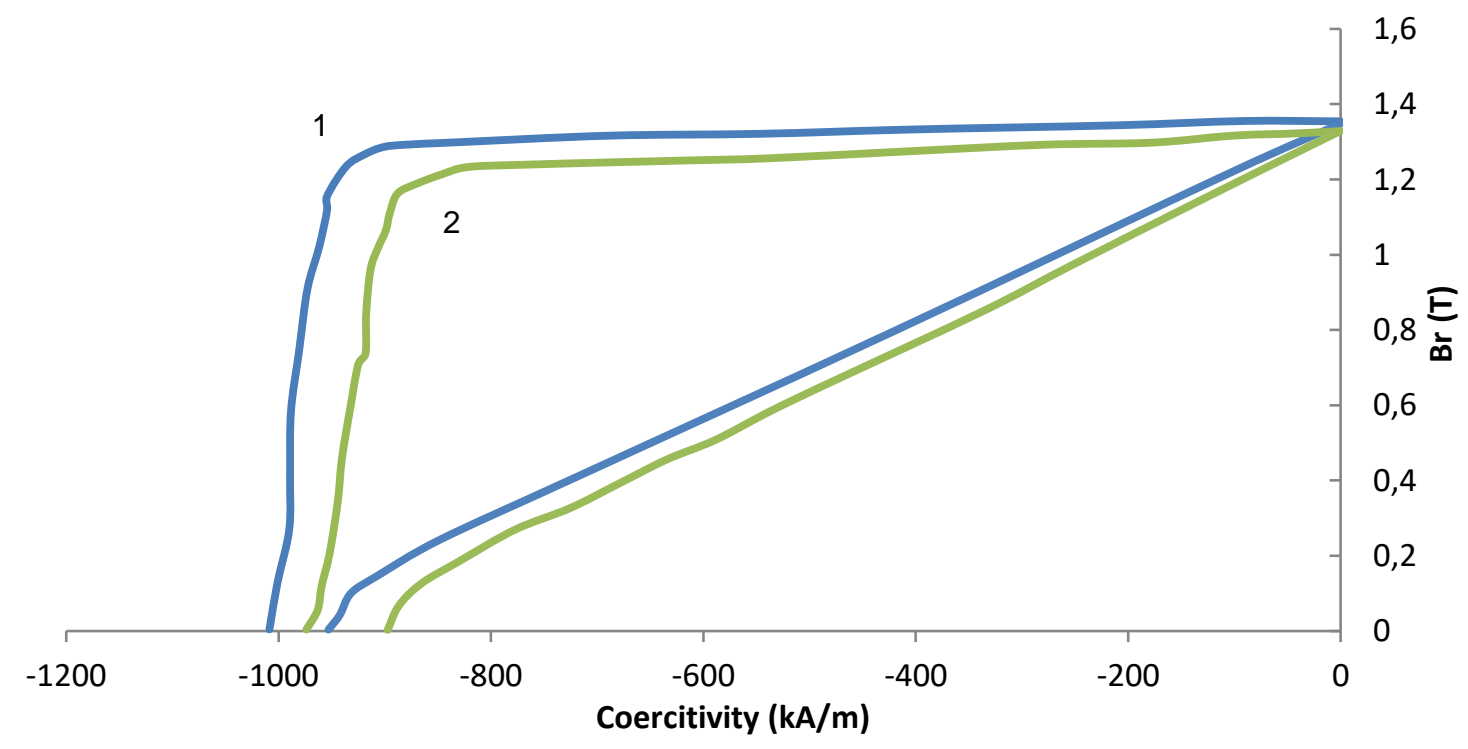

Figure 4 Magnetization reversal curves of sintered magnets prepared by powder blending procedure in using (1) $\mathrm{Pr}_{3} \mathrm{Co}_{0.6} \mathrm{Cu}_{0.4} \mathrm{H}_{\mathrm{x}}$ and (2) $\mathrm{PrH}_{\mathrm{x}}$ additions. 
Table 3 Magnetic hysteretic characteristics of sintered magnets prepared by powder blending procedure in using $\mathrm{Pr}_{3} \mathrm{Co}_{0.6} \mathrm{Cu}_{0.4} \mathrm{H}_{\mathrm{x}}$ and $\mathrm{PrH}_{\mathrm{x}}$ additions

\begin{tabular}{|c|c|c|c|c|}
\hline Addition & $\boldsymbol{B}_{\boldsymbol{r}}(\mathrm{T})$ & ${ }_{j} \boldsymbol{H}_{\boldsymbol{c}}(\mathrm{kA} / \mathrm{m})$ & $\boldsymbol{H}_{\boldsymbol{k}}(\mathrm{kA} / \mathrm{m})$ & $(\boldsymbol{B H}) \max \left(\mathrm{kJ} / \mathrm{m}^{3}\right)$ \\
\hline $2 \mathrm{wt} \% \mathrm{Pr}_{3} \mathrm{Co}_{0.6} \mathrm{Cu}_{0.4} \mathrm{H}_{\mathrm{x}}$ & 1.35 & 1004 & 943 & 349 \\
\hline $2 \mathrm{wt} \% \mathrm{PrH}_{\mathrm{x}}$ & 1.33 & 973 & 874 & 317 \\
\hline
\end{tabular}

As is seen, in using the $\mathrm{Pr}_{3} \mathrm{Co}_{0.6} \mathrm{Cu}_{0.4}$ addition, both the remanence and coercive force of sintered magnet increase as compared to those of the magnet prepared with $\mathrm{PrH}_{\mathrm{x}}$ hydride. Moreover, the maximum energy product increases and squareness of the hysteresis loop improves.

The higher magnetic hysteresis characteristics of the magnet prepared with the $\mathrm{Pr}_{3} \mathrm{Co}_{0.6} \mathrm{Cu}_{0.4} \mathrm{H}_{\mathrm{x}}$ addition are related to the structuring of grain boundaries, namely, the improvement of their both wetting at the expense of low-melting copper-containing composition and magnetic isolation.

\section{CONCLUSIONS}

- The phase composition of the hydrogenated $\mathrm{Pr}_{3} \mathrm{Co}_{0.6} \mathrm{Cu}_{0.4}$ addition was studied by SEM, EMA, and Xray diffraction. The $\mathrm{Pr}_{3} \mathrm{Co}_{0.6} \mathrm{Cu}_{0.4} \mathrm{H}_{\mathrm{x}}$ composition is undergone the hydrogenolysis and is shown to be multiphase and include Pr-rich components, such as $\mathrm{Pr}, \mathrm{PrH}_{x}$, and $\mathrm{PrCu}$ and Co phases. All these components are known to exhibit different diffusion behavior in the course of manufacturing the sintered magnet.

- The $\operatorname{Pr}, \mathrm{PrH}_{\mathrm{x}}$, and $\mathrm{PrCu}$ components modify the grain boundaries of sintered magnet and improve the wetting between $\mathrm{Nd}_{2} \mathrm{Fe}_{14} \mathrm{~B}$-based grains and $\mathrm{Nd}(\mathrm{Pr})$-rich intergranular phase. Fine Co particles can diffuse into the $\mathrm{Nd}_{2} \mathrm{Fe}_{14} \mathrm{~B}$-based grains to form $\mathrm{Nd}_{2} \mathrm{Fe}_{14} \mathrm{~B}$-core/ $\mathrm{Nd}_{2}(\mathrm{Fe}, \mathrm{Co}){ }_{14} \mathrm{~B}$-shell microstructure, which improves thermal stability of the coercive force.

- The hysteretic properties of the sintered magnet prepared from the strip-casting alloy in using the hydrogenated $\mathrm{Pr}_{3} \mathrm{CO}_{0.6} \mathrm{Cu}_{0.4} \mathrm{H}_{\mathrm{x}}$ addition are shown can be improved as compared to those reached in the case of application of $\mathrm{PrH}_{\mathrm{x}}$ hydride in the powder mixture.

\section{ACKNOWLEDGEMENTS}

This study was supported by the Ministry of Science and Higher Education of the Russian Federation, Agreement no. 14.616.21.0093 (unique identification number RFMEFI61618X0093) and the Ministry of Education, Youth, and Sports of the Czech Republic, project no. LTARF18031.

\section{REFERENCES}

[1] LIU, W. Q., SUN, H., YI, X. F., LIU, X. C., ZHANG, D. T., YUE, M., ZHANG, J. X. Coercivity enhancement in NdFe-B sintered permanent magnet by Dy nanoparticles doping. Journal of Alloys and Compounds. 2010, vol. 501, pp. 67-69.

[2] WATANABE, N., ITAKURA, M., NISHIDA, M. Microstructure of high coercivity Nd-Fe-Co-Ga-B hot-deformed magnet improved by the Dy diffusion treatment. Journal of Alloys and Compounds. 2013, vol. 557, pp. 1-4.

[3] SEPEHRI-AMIN, H., LIU, L., OHKUBO, T., YANO, M., SHOJI, T., KATO, A., SCHREFL, T., HONO, K. Microstructure and temperature dependent of coercivity of hot-deformed $\mathrm{Nd}-\mathrm{Fe}-\mathrm{B}$ magnets diffusion processed with Pr-Cu alloy. Acta Materialia. 2015, vol. 99, pp. 297-306.

[4] KOMURO, M., SATSU, Y., SUZUKI, H. Increase of coercivity and composition distribution in fluoride-diffused NdFeB sintered magnets treated by fluoride solutions. IEEE Transactions of Magnets. 2010, vol. 46, pp. 38313833.

[5] NI, J., MA, T., YAN, M. Improvement of corrosion resistance in Nd-Fe-B magnets through grain boundaries restructuring. Materials Letters. 2012, vol. 75, pp. 1-3. 
[6] LU, K., BAO, X., TANG, M., SUN, L., LI, J., GAO, X. Influence of annealing on microstructural and magnetic properties of Nd-Fe-B magnets by grain boundary diffusion with $\mathrm{Pr}-\mathrm{Cu}$ and Dy-Cu alloys. Journal of Magnetism and Magnetic Materials. 2017, vol. 441, pp. 517-522.

[7] ZHANG, Y., MA, T., LIU, X., LIU, P., JIN, J., ZOU, J., YAN, M. Coercivity enhancement of Nd-Fe-B sintered magnets with intergranular adding (Pr, Dy, Cu)-Hx powders. Journal of Magnetism and Magnetic Materials. 2016, vol. 399, pp. 159-163.

[8] TANG, M., BAO, X., ZHOU, Y., LU, K., LI, J., GAO, X. Microstructure and annealing effects of NdFeB sintered magnets with Pr-Cu boundary addition. Journal of Magnetism and Magnetic Materials. 2020, vol. 505, 166749.

[9] WAN, F., ZHANG, Y., HAN, J., LIU, S., LIU, T., ZHOU, L., FU, J., ZHOU, D., ZHANG, X., YANG, J., YANG, Y., CHEN, J., DENG, Z. Coercivity enhancement in Dy-free Nd-Fe-B sintered magnets by using Pr-Cu alloy. Journal of Applied Physics. 2014, vol. 115, 203910.

[10] JIN, C., CHEN, R., YIN, W., TANG, X., WANG, Z., JU, J., LEE, D., YAN, A. Magnetic properties and phase evolution of sintered Nd-Fe-B magnets with intergranular addition of $\mathrm{Pr}-\mathrm{Co}$ alloy. Journal of Alloys and Compounds. 2016, vol. 670, pp. 72-77.

[11] MASSALSKI, T.B., OKAMOTO, H., SUBRAMANIAN, P.R., KACPRZAK, L. Binary Alloy Phase Diagrams. ASM International, Materials Park. 1990, 2nd Edition.

[12] SKOTNICOVA, K., BURKHANOV, G. S., KOLCHUGINA, N. B., Kursa, M., CEGAN, T., LUKIN, A. A., ZIVOTSKY, O., PROKOFEV, P. A., JURICA, J., LI, Y. Structural and magnetic engineering of (Nd, Pr, Dy, Tb)-Fe-B sintered magnets with $\mathrm{Tb}_{3} \mathrm{Co}_{0.6} \mathrm{Cu}_{0.4} \mathrm{H}_{\mathrm{x}}$ composition in the powder mixture. Journal of Magnetism and Magnetic Materials. 2020, vol. 498, 166220.

[13] SKOTNICOVA, K., PROKOFEV, P. A., KOLCHUGINA, N. B., BURKHANOV, G. S., LUKIN, A. A., KOSHKID'KO, Y. S., CEGAN, T., DRULIS, H., ROMANOVA, T., DORMIDONTOV, N. A. Application of a $\mathrm{Dy}_{3} \mathrm{Co}_{0.6} \mathrm{Cu}_{0.4} \mathrm{H}_{\mathrm{x}}$ Addition for Controlling the Microstructure and Magnetic Properties of Sintered Nd-Fe-B Magnets. Materials (Basel). 2019, vol. 12(24): 4235.

[14] NI, J., MA, T., YAN, M. Changes of microstructure and magnetic properties of Nd-Fe-B sintered magnets by doping Al-Cu. Journal of Magnetism and Magnetic Materials. 2011, vol. 323, pp. 2549-2553.

[15] SEPEHRI-AMIN, H., UNE, Y., OHKUBO, T., HONO, K., SAGAWA, M. Microstructure of fine-grained Nd-Fe-B sintered magnets with high coercivity. Scripta Materialia. 2011, vol.65, pp. 396-399.

[16] LEE, M.-W., BAE, K.-H., LEE, S.-R., KIM, H.-J., JANG, T.-S. Microstructure and Magnetic Properties of NdFeB Sintered Magnets Diffusion-Treated with Cu/AI Mixed Dy-Co Alloy-Powder. Archives Metallurgy and Materials. 2017, vol. 62 (2B), pp. 1263-1266. 